\title{
Can Atlantic salmon smolt twice? Endocrine and biochemical changes during smolting
}

\author{
J. Mark Shrimpton, Björn Thrandur Björnsson, and Stephen D. McCormick
}

\begin{abstract}
Smolting is characterized by morphological and physiological changes, some of which are reversible if fish remain in freshwater. Whether fish that smolt in the first year will repeat physiological changes associated with smolting a second time is not known. To assess whether Atlantic salmon (Salmo salar) can smolt more than once, we sampled hatchery-reared Atlantic salmon at monthly intervals for 2 years beginning the fall after hatching. Fish showed differences in rate of growth and were easily differentiated by size into upper mode (UM) and lower mode (LM) by the first fall. In the first spring, gill $\mathrm{Na}^{+}, \mathrm{K}^{+}$-ATPase activity of UM and LM fish increased six- and three-fold, respectively. Plasma growth hormone levels in spring were significantly elevated in UM fish but not in LM. Plasma cortisol levels changed little and gill corticosteroid receptor concentration did not differ between the groups. During the summer, gill $\mathrm{Na}^{+}, \mathrm{K}^{+}$-ATPase activity declined in both groups and remained low until the next spring. The second spring, growth hormone levels did not increase significantly and cortisol levels increased. The increase in gill $\mathrm{Na}^{+}, \mathrm{K}^{+}-\mathrm{ATPase}$ activity and cortisol and high saltwater tolerance indicate that UM Atlantic salmon can smolt in two consecutive years.
\end{abstract}

Résumé : La smoltification se caractérise par des changements morphologiques et physiologiques dont certains sont réversibles si les poissons restent en eau douce. Nous ne savons pas si les poissons qui smoltifient la première année vont reproduire une deuxième fois les changements physiologiques associés à la smoltification. Pour déterminer si le saumon atlantique peut subir plus d'une smoltification, nous avons échantillonné des saumons d'élevage à intervalle mensuel pendant deux ans à partir de l'automne qui a suivi l'éclosion. Les poissons présentaient des différences dans le taux de croissance, et étaient faciles à classer par la taille en mode supérieur et en mode inférieur dès le premier automne. Au premier printemps, l'activité de la $\mathrm{Na}^{+}, \mathrm{K}^{+}$-ATPase dans les branchies augmentait respectivement six fois et trois fois chez les poissons de mode supérieur et de mode inférieur. Les niveaux d'hormone de croissance dans le plasma au printemps étaient nettement élevés chez les poissons de mode supérieur, mais pas chez les autres. Les niveaux de cortisol dans le plasma ont peu changé, et la concentration des récepteurs de corticostéroïdes dans les branchies ne variait pas d'un groupe à l'autre. Pendant l'été, l'activité de la $\mathrm{Na}^{+}, \mathrm{K}^{+}$-ATPase dans les branchies baissait chez les deux groupes, et elle est demeurée basse jusqu'au printemps suivant. Au deuxième printemps, les niveaux d'hormone de croissance n'ont pas augmenté de façon significative, mais les niveaux de cortisol ont monté. L'augmentation de l'activité de la $\mathrm{Na}^{+}, \mathrm{K}^{+}$-ATPase dans les branchies et la hausse du cortisol, ainsi que la tolérance à une eau fortement salée, indiquent que les saumons atlantiques de mode supérieur peuvent connaître une smoltification deux années consécutives.

[Traduit par la Rédaction]

\section{Introduction}

At the time of downstream migration in spring, many anadromous salmonids undergo parr-smolt transformation, a complex developmental process that involves morphological, physiological, and behavioural changes that are adaptive for

Received November 9, 1999. Accepted July 17, 2000.

J15436

J.M. Shrimpton ${ }^{1}$ and S.D. McCormick. Conte Anadromous

Fish Research Center, Biological Resources Division,

U.S. Geological Survey, Turners Falls, MA 01376, U.S.A.,

and Department of Biology, University of Massachusetts,

Amherst, MA 01002, U.S.A.

B.Th. Björnsson. Fish Endocrinology Laboratory, Department of Zoology, Göteborg University, Box 463, S-40530

Göteborg, Sweden.

${ }^{1}$ Author to whom all correspondence should be sent at the following address: Biology Program, University of Northern British Columbia, 3333 University Way, Prince George, BC V2N 4Z9, Canada. e-mail: shrimptm@unbc.ca downstream migration, seawater entry, and long-term seawater survival. An increase in gill $\mathrm{Na}^{+}, \mathrm{K}^{+}$-ATPase activity is correlated with increased seawater tolerance and is often used as an indicator of smolting (McCormick and Saunders 1987). Increases in photoperiod stimulate the parr-smolt transformation (Hoar 1988; Björnsson et al. 1995), but the magnitude of physiological changes induced by photoperiod are limited by growth rate and size of fish. In Atlantic salmon (Salmo salar), bimodal growth distribution is common in hatchery- and laboratory-reared fish (Thorpe et al. 1980) and has also been documented in wild populations (Heggenes and Metcalfe 1991). Under normal hatchery conditions, the larger, faster growing upper mode (UM) fish will smolt in their first spring as 1+ juveniles, whereas the smaller, slower growing lower mode (LM) fish require an additional year of growth before smolting as $2+$ juveniles. To date, most of the laboratory studies examining physiological changes associated with smolting in Atlantic salmon have focused on UM fish. The limited number of studies on LM fish, however, indicate that these fish also exhibit seasonal changes in gill $\mathrm{Na}^{+}, \mathrm{K}^{+}$-ATPase activity, but the mag- 
nitude is significantly less than that seen for UM fish (Duston 1994; Shrimpton and McCormick 1998a).

Increases in salinity tolerance that occur during smolting are known to be reversible. Fish that are maintained in freshwater beyond the period of normal spring migration lose their elevated capacity to osmoregulate in seawater (Lundqvist et al. 1989; Duston et al. 1991; McCormick et al. 1997). Research on wild Atlantic salmon indicates that loss of smolt characteristics also occurs under some conditions in naturally migrating smolts (McCormick et al. 1999). It is believed that fish that lose smolt characteristics cease migration and continue to reside in the river. Fish that morphologically appear to be smolts have been captured behind dams with low levels of gill $\mathrm{Na}^{+}, \mathrm{K}^{+}$-ATPase activity (S.D. McCormick, unpublished data). It is not known whether or not these fish that have undergone the parr-smolt transformation will repeat this process the following spring.

One of the hormones most closely associated with the regulation of smoltification is growth hormone $(\mathrm{GH})$ (Björnsson 1997). Seasonal increases in GH are correlated with increased gill $\mathrm{Na}^{+}, \mathrm{K}^{+}$-ATPase activity in Atlantic salmon (Boeuf et al. 1990; McCormick et al. 1995), and GH treatment stimulates gill $\mathrm{Na}^{+}, \mathrm{K}^{+}$-ATPase activity (Boeuf et al. 1990). There is also considerable evidence that cortisol stimulates gill $\mathrm{Na}^{+}, \mathrm{K}^{+}$-ATPase activity (see review by McCormick 1995), and increased $\mathrm{Na}^{+}, \mathrm{K}^{+}$-ATPase activity has been found to closely correlate with increased plasma cortisol levels (Shrimpton and McCormick 1998a). GH and cortisol also exert synergistic effects on gill $\mathrm{Na}^{+}, \mathrm{K}^{+}$-ATPase activity and saltwater tolerance in salmonids (Madsen 1990).

By following a bimodal population of Atlantic salmon over a period of 2 years, it has been possible to compare and contrast the development of saltwater tolerance between the UM and LM groups and to determine seasonal versus smoltrelated changes in juvenile Atlantic salmon. Length, weight, physical appearance, gill $\mathrm{Na}^{+}, \mathrm{K}^{+}$-ATPase activity, corticosteroid receptor $(\mathrm{CR})$ concentration and affinity, plasma cortisol and GH levels, and saltwater tolerance were measured at approximately monthly intervals for 21 months. These parameters were used to evaluate the ability of Atlantic salmon to smolt twice.

\section{Materials and methods}

\section{Fish and sampling procedures}

Juvenile Atlantic salmon were raised at the White River $\mathrm{Na}$ tional Fish Hatchery (Bethel, Vt.). Throughout the study, fish were maintained in 4-m circular concrete ponds supplied with well water while under natural photoperiod and fed to satiation daily with automatic feeders and hand feeding. Temperature of the water during the study is shown in Fig. 1. The fish were not graded; UM and LM fish were reared in common tanks.

At approximately monthly intervals from September 1994 to May 1996, fish were sampled from two circular ponds. Fish were not fed the morning of sampling, which occurred between 10:00 and 13:00 eastern standard time. Eight fish were captured from a single pond and rapidly transferred to a bucket containing $200 \mathrm{mg}$ tricaine methanesulphonate $\mathrm{L}^{-1}$ (neutralized and buffered with sodium bicarbonate, $\mathrm{pH}$ 7.0). Once the fish were anesthetized, fork length and body weight were measured. Blood was collected in heparinized capillary tubes after the caudal peduncle was severed (for fish $<20 \mathrm{~g}$ ) or in heparinized syringes from the caudal
Fig. 1. (a) Seasonal change in water temperature for rearing ponds at the White River Nation Fish Hatchery in Bethel, Vt., and $(b)$ weight of juvenile Atlantic salmon sampled from September 1994 to May 1996. UM ( $\mathbf{\Delta})$ are fish that smolt after 1 year and LM (O) are fish that smolt after 2 years. UM fish were significantly larger than LM fish at all sampling intervals except for the first September. Values are means \pm 1 SEM.

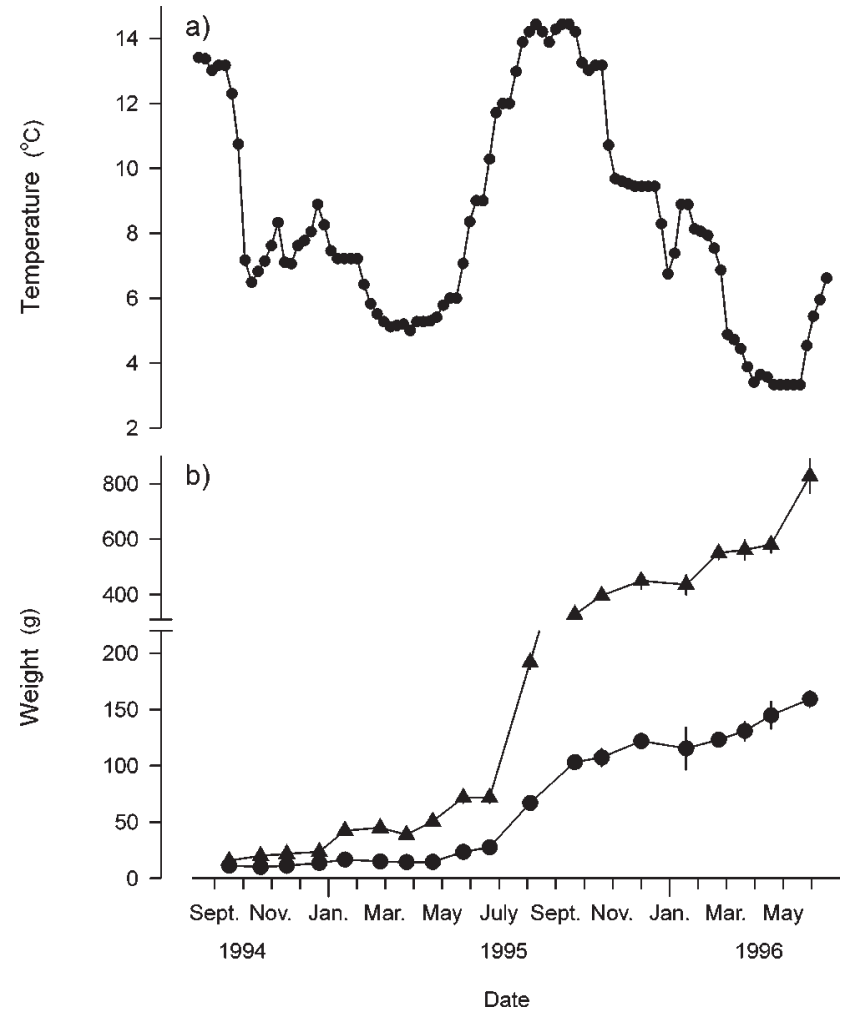

vasculature (for fish $>20 \mathrm{~g}$ ). Collection of blood was complete within $5 \mathrm{~min}$ of first disturbing the fish in order to avoid a stressrelated rise in cortisol (Sumpter et al. 1986). Blood was stored on ice for less than $30 \mathrm{~min}$, centrifuged at $3000 \times g$ for $5 \mathrm{~min}$, and the plasma removed and frozen on dry ice. A gill biopsy (six to eight primary gill filaments) was taken and placed in $100 \mu \mathrm{L}$ of SEI (150 mM sucrose, $10 \mathrm{mM} \mathrm{Na}{ }_{2}$ EDTA, $50 \mathrm{mM}$ imidazole, $\mathrm{pH}$ 7.3) on ice for determining $\mathrm{Na}^{+}, \mathrm{K}^{+}$-ATPase activity. Samples were frozen on dry ice within $30 \mathrm{~min}$. Gill tissue was removed and placed in $2 \mathrm{~mL}$ of TEMS $\left(10 \mathrm{mM}\right.$ Tris- $\mathrm{HCl}, 1 \mathrm{mM} \mathrm{Na} \mathrm{N}_{2}$ EDTA, $12 \mathrm{mM}$ monothioglycerol, $20 \mathrm{mM}$ sodium molybdate, $10 \% \mathrm{v} / \mathrm{v}$ glycerol, $\mathrm{pH}$ 7.4) and frozen immediately on dry ice for later analysis of CR concentration and affinity. Fish from the second pond were sampled in the same manner. Following sampling, fish were dissected to determine sex and gonad size. All samples were stored at $-80^{\circ} \mathrm{C}$ until analyses. With the exception of the first sample date (September 1994), there was a clear difference in size between UM and LM fish in each pond, and eight large fish and eight small fish were selected on each occasion. Saunders et al. (1994) showed that there was little movement between modal groups throughout rearing in the first year. Over the second year, the difference in size between the modal groups became so large that it is unlikely that fish could have moved between the modal groups. From August 1995 to the end of the study, some of the LM fish showed gonadal development and signs of sexual maturation and were excluded from the analysis. Consequently, fewer than eight LM fish are included in the sample set; $n=7$ for August 1995, $n=5$ for Septem- 
ber and October 1995 and March, April, and May 1996, and $n=4$ for November 1995 and January and February 1996.

\section{Analysis of gill $\mathrm{Na}^{+}, \mathrm{K}^{+}$-ATPase activity}

Gill $\mathrm{Na}^{+}, \mathrm{K}^{+}$-ATPase activity was measured according to the microassay protocol of McCormick (1993). Gill filaments were homogenized in SEI buffer containing $0.1 \%$ sodium deoxycholate. Following centrifugation $(3000 \times g$ for $0.5 \mathrm{~min})$ to remove debris, $\mathrm{Na}^{+}, \mathrm{K}^{+}$-ATPase activity was determined by linking ATP hydrolysis to the oxidation of $\mathrm{NADH}$, measured at $340 \mathrm{~nm}$ for $10 \mathrm{~min}$ at $25^{\circ} \mathrm{C}$, in the presence and absence of $0.5 \mathrm{mM}$ ouabain. Protein content in the gill homogenate was measured using a bicinchoninic acid protein assay (Pierce, Rockford, Ill.). Specific activities were expressed as micromoles of ADP per milligram of protein per hour.

\section{Determination of plasma GH levels}

Plasma GH levels were measured in duplicate samples using a specific double-antibody salmon GH radioimmunoassay outlined by Björnsson et al. (1994). Recombinant chum salmon (Oncorhynchus keta) GH (Kyowa Hakko Kogyo, Tokyo, Japan) was used for iodination and assay standards. The primary antibody (HU-85) was raised in rabbit against chum salmon $\mathrm{GH}$, and the secondary antibody used was goat antirabbit IgG (R-0881; Sigma, St. Louis, Mo.).

\section{Determination of plasma cortisol levels}

Plasma cortisol levels were quantified using a competitive solidphase microtitre enzyme immunoassay following the protocol of Carey and McCormick (1998). Rabbit anticortisol antibodies (cat. F3-314, lot 345-10-22-80; Endocrine Science Products, Calabasas Hills, Calif.) were coated to microtiter plates. Cortisol - horseradish peroxidase conjugate (gift from Coralee Munro, University of California, Davis, Calif.) was used as the label. Colour development was with 3,3',5,5'-tetramethylbenzidine containing $0.01 \%$ hydrogen peroxide. The reaction was terminated with $0.5 \mathrm{M} \mathrm{HCl}$ and absorbance read at $450 \mathrm{~nm}$.

\section{Corticosteroid receptor analysis}

CRs were measured on the cytosol fraction of gill tissue using the method of Maule and Schreck (1991) as modified by Shrimpton and McCormick (1998b). Binding studies were conducted with $\left[{ }^{3} \mathrm{H}\right]$ triamcinolone acetonide (1,4-pregnadien- $9 \alpha$-fluoro- $11 \beta, 16 \alpha, 17 \alpha, 21$ tetrol-3,20-dione-16,17-acetonide) with a specific activity of $43.8 \mathrm{Ci}$. $\mathrm{mmol}^{-1}$ (Dupont-NEN) $(1 \mathrm{Ci}=37 \mathrm{GBq})$. One hundred microlitres of gill cytosol was incubated in aliquots with $100 \mu \mathrm{L}$ of buffer containing $\left[{ }^{3} \mathrm{H}\right]$ triamcinolone acetonide with or without a 500 -fold excess of cold triamcinolone acetonide for $2 \mathrm{~h}$ on ice. Final concentrations of $\left[{ }^{3} \mathrm{H}\right]$ triamcinolone acetonide in each assay were $0.1,0.3,1,3$, and $6 \mathrm{nM}$. After incubation, unbound steroids were removed by incubation for $10 \mathrm{~min}$ with $0.5 \mathrm{~mL}$ of TEMS containing $2.5 \%(\mathrm{w} / \mathrm{v})$ activated charcoal and $0.25 \%(\mathrm{w} / \mathrm{v})$ dextran and then centrifuged at $3000 \times g$ for $15 \mathrm{~min}$. Supernatant $(0.5 \mathrm{~mL})$ was added to $3 \mathrm{~mL}$ of aqueous counting scintillant and radioactivity counted. Specific binding was determined by subtracting nonspecific bound from the total bound.

The origin of CRs in the gills may be cytosolic or nuclear but are referred to as cytosolic, as they are found in the cytosol fraction following tissue processing (Welshons and Jordan 1987). The CR concentration measured reflects the unbound receptor population. The equilibrium dissociation constant $\left(K_{\mathrm{d}}\right)$ and the concentration of CR sites $\left(B_{\max }\right)$ were calculated according to Scatchard (1949). The $B_{\max }$ was divided by the homogenate protein concentration, and CR concentration was expressed as femtomoles per milligram of protein. To estimate cooperativity between CR and ligand, the Hill coefficient was calculated according to Sandor et al. (1984).

\section{Saltwater challenges}

On January 18, 1996, and April 17, 1996, juvenile Atlantic salmon were transported from the White River National Fish Hatchery in Bethel, Vt., to the Conte Anadromous Fish Research Center in Turner Falls, Mass. Upon arrival, fish were transferred to a recirculating system containing 35\%o saltwater. After $24 \mathrm{~h}$, fish were removed from salt water, killed by concussion, and length and weight measured. Blood was collected in heparinized syringes from the caudal vasculature. Blood was stored on ice for less than $30 \mathrm{~min}$, centrifuged at $3000 \times g$ for $5 \mathrm{~min}$, and the plasma removed and frozen at $-80^{\circ} \mathrm{C}$. Plasma chloride concentration was measured on a Labconco model 442-5000 digital chloridometer.

\section{Calculations and statistical analysis}

Condition factor $(\mathrm{CF})$ was calculated as (weight/length $\left.{ }^{3}\right) \times 100$. For seasonal changes in length, weight, $\mathrm{CF}$, gill $\mathrm{Na}^{+}, \mathrm{K}^{+}$-ATPase activity, plasma GH, and gill $\mathrm{CR} B_{\max }$ and $K_{\mathrm{d}}$, a two-way analysis of variance (ANOVA) was used to determine whether time of sampling or group had a significant effect on these variables. Plasma cortisol data were not normally distributed; a nonparametric ANOVA on ranked data was used to determine differences between sample date and group. When factors were found to be statistically significant, Tukey's test was used to determine differences between the individual groups and time interval. For the saltwater challenge data, a two-way ANOVA was used to determine differences between groups and between sample dates, followed by a Tukey's test to determine differences between individual groups. Statistical significance was taken at a level of $p<0.05$. All values are expressed as means \pm 1 SEM.

\section{Results}

\section{Seasonal changes}

Considerable variation in growth was seen in the Atlantic salmon used in this study (Fig. 1). Length and weight of UM fish differed significantly from those of LM fish at every time point during the study from October of 1994 to the end. There was a rapid increase in size of fish in the first spring and early summer, and this increase was much greater for UM fish.

In the first year of the study, $\mathrm{CF}$ declined significantly (20\%) over the winter months in both UM and LM fish. The lowest CF was observed in April for UM fish and in March for LM fish. Both groups showed an increase in CF over the summer, but CF increased more rapidly in LM fish and the highest values were recorded in August for LM fish and in December for UM fish. As was seen in the first year of the study, CF declined significantly from November to March in UM and LM fish.

In April, UM fish developed silvering and dark fin margins characteristic of smolts, and these fish remained silver until the end of the study; they did not regain parr marks at any time after their first spring. LM fish did not lose parr marks during the first spring but developed the silver colouration characteristic of smolts during the second spring.

Seasonal changes in gill $\mathrm{Na}^{+}, \mathrm{K}^{+}$-ATPase activity are shown in Fig. 2. Enzyme activity changed significantly over the study and between groups. In January, enzyme activity began to rise in UM fish and had risen significantly by March (Fig. 2). This contrasted LM fish, which showed no 
Fig. 2. (a) $\mathrm{CF}$ of and (b) gill $\mathrm{Na}^{+}, \mathrm{K}^{+}$-ATPase activity in juvenile Atlantic salmon sampled throughout the study. See Fig. 1 for description of groups. $\boldsymbol{\Delta}$, UM fish; $\boldsymbol{O}$, LM fish. *Significantly different from LM fish for the same sampling interval. Values are means \pm 1 SEM.
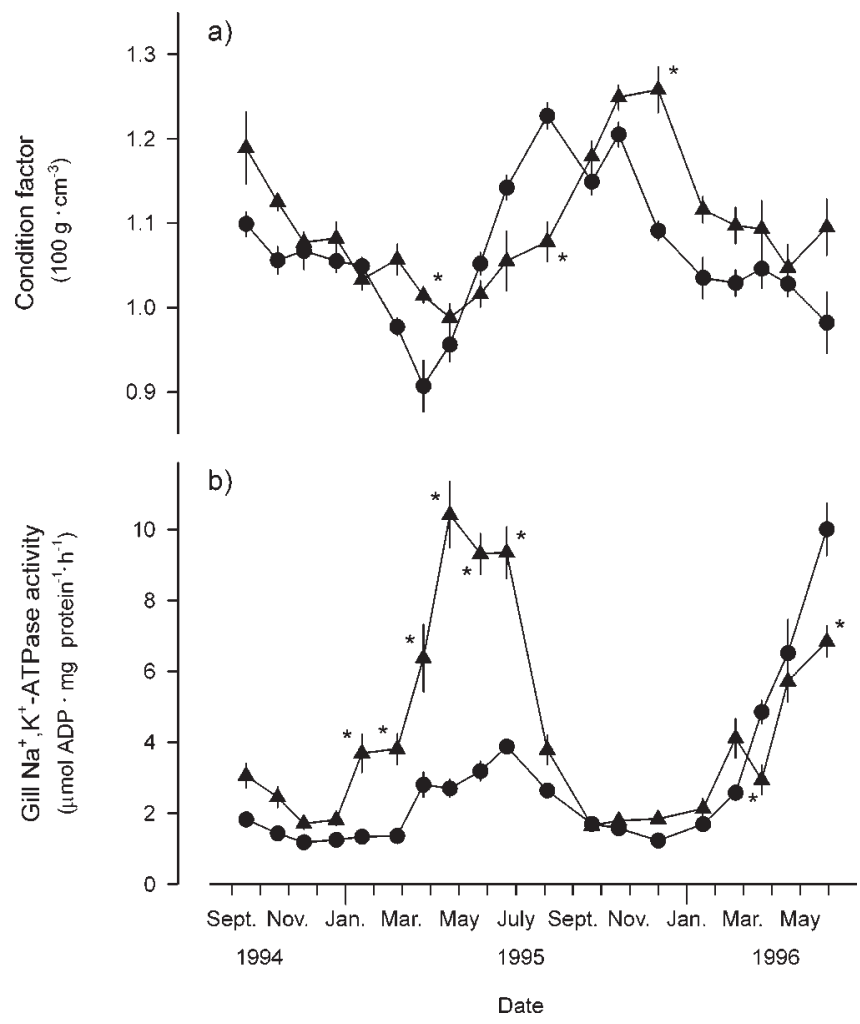

increase in gill $\mathrm{Na}^{+}, \mathrm{K}^{+}$-ATPase activity until March. Gill $\mathrm{Na}^{+}, \mathrm{K}^{+}$-ATPase activity was highest in April, May, and June for both groups, but peak levels were threefold greater in UM fish $\left(9 \mu \mathrm{mol}\right.$ ADP.mg protein $\left.{ }^{-1} \cdot \mathrm{h}^{-1}\right)$ than in LM fish (3 $\mu$ mol ADP.mg protein $\left.{ }^{-1} \cdot \mathrm{h}^{-1}\right)$. Gill $\mathrm{Na}^{+}, \mathrm{K}^{+}$-ATPase activity declined after June in both groups and remained low (approximately $2 \mu \mathrm{mol}$ ADP.mg protein ${ }^{-1} \cdot \mathrm{h}^{-1}$ ) until the next spring. Both UM and LM fish showed significant increases in gill $\mathrm{Na}^{+}, \mathrm{K}^{+}$-ATPase activity by March of the second spring, with the highest activities in May. At this time, levels of $\mathrm{Na}^{+}, \mathrm{K}^{+}$-ATPase in UM fish were approximately $70 \%$ of those in LM fish. Gill $\mathrm{Na}^{+}, \mathrm{K}^{+}$-ATPase activity of LM fish during the second spring were similar to those of UM fish during the first spring.

Plasma GH and cortisol levels showed seasonal changes that varied in magnitude between the two years (Fig. 3). There were signficant differences between modal groups and over the duration of the study as well as a significant interaction effect. In the first year of the study, the endocrine changes were dominated by increases in plasma $\mathrm{GH}$ : a fourfold increase from $1.1 \mathrm{ng} \cdot \mathrm{mL}^{-1}$ in January to $4.2 \mathrm{ng} \cdot \mathrm{mL}^{-1}$ in April in UM fish and an $86 \%$ increase from $0.6 \mathrm{ng} \cdot \mathrm{mL}^{-1}$ in January to $1.1 \mathrm{ng} \cdot \mathrm{mL}^{-1}$ in April in LM fish. Plasma GH levels were significantly greater in UM fish than in LM fish in April and May (Fig. 3). In the second spring, however, increases in plasma GH in both UM and LM fish were smaller than the previous year and did not exceed $1.5 \mathrm{ng} \cdot \mathrm{mL}^{-1}$.
Fig. 3. (a) Plasma GH and (b) plasma cortisol levels in juvenile Atlantic salmon. See Fig. 1 for description of groups. $\boldsymbol{\Delta}, \mathrm{UM}$ fish; $\bigcirc$, LM fish. *Significantly different from LM fish for the same sampling interval. Values are means \pm 1 SEM.
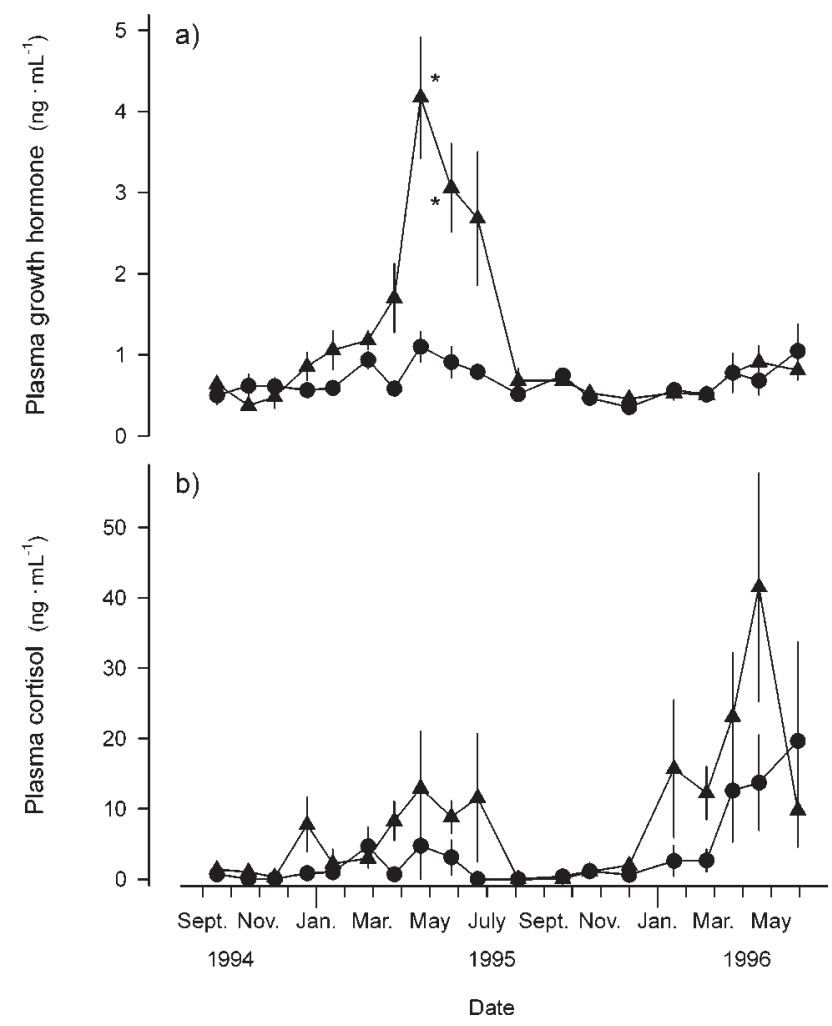

Plasma GH levels between the groups did not differ significantly.

Plasma cortisol levels changed significantly over time, but there was no significant difference between the modal groups. Cortisol levels increased from less than $2 \mathrm{ng} \cdot \mathrm{mL}^{-1}$ in both groups in January to over $8 \mathrm{ng} \cdot \mathrm{mL}^{-1}$ (UM) and $3 \mathrm{ng} \cdot \mathrm{mL}^{-1}(\mathrm{LM})$ in April and were low over the summer months $\left(<2 \mathrm{ng} \cdot \mathrm{mL}^{-1}\right)$. In the second spring, a much more pronounced increase in plasma cortisol was observed compared with the first spring, with maximum levels over $40 \mathrm{ng} \cdot \mathrm{mL}^{-1}$ measured in April for UM fish and over $20 \mathrm{ng} \cdot \mathrm{mL}^{-1}$ measured in May for LM fish.

Gill CR $B_{\max }$ differed significantly over time but not between the modal groups (Fig. 4). Gill CR $B_{\max }$ increased threefold in both UM and LM fish, peaking in August; gill CR $B_{\max }$ was $86.4 \pm 6.2 \mathrm{fmol} \cdot \mathrm{mg}$ protein $^{-1}$ for $\mathrm{LM}$ and $91.0 \pm 5.0 \mathrm{fmol} \cdot \mathrm{mg}$ protein ${ }^{-1}$ for UM fish. After the peak in August, gill CR $B_{\max }$ declined and dropped $60 \%$ in both UM and LM fish by December. During winter, gill CR $B_{\max }$ increased approximately threefold in all groups. Highest values of gill CR $B_{\max }$ were seen in February for UM fish and in March for LM fish. In UM and LM fish, gill CR $B_{\max }$ declined significantly by May.

Significant differences in gill CR $K_{\mathrm{d}}$ occurred over time and between groups. Gill CR $K_{\mathrm{d}}$ was lowest in the fall and increased during the first spring for both UM and LM fish. By May, gill CR $K_{\mathrm{d}}$ had increased $50 \%$ for UM fish and $45 \%$ for LM fish. Values of gill CR $K_{\mathrm{d}}$ did not differ be- 
Fig. 4. Seasonal changes in (a) gill CR $B_{\max }$ and (b) gill CR $K_{\mathrm{d}}$ for juvenile Atlantic salmon. See Fig. 1 for description of groups. $\boldsymbol{\Delta}$, UM fish; - LM fish. *Significantly different from LM fish for the same sampling interval. Values are means \pm 1 SEM.

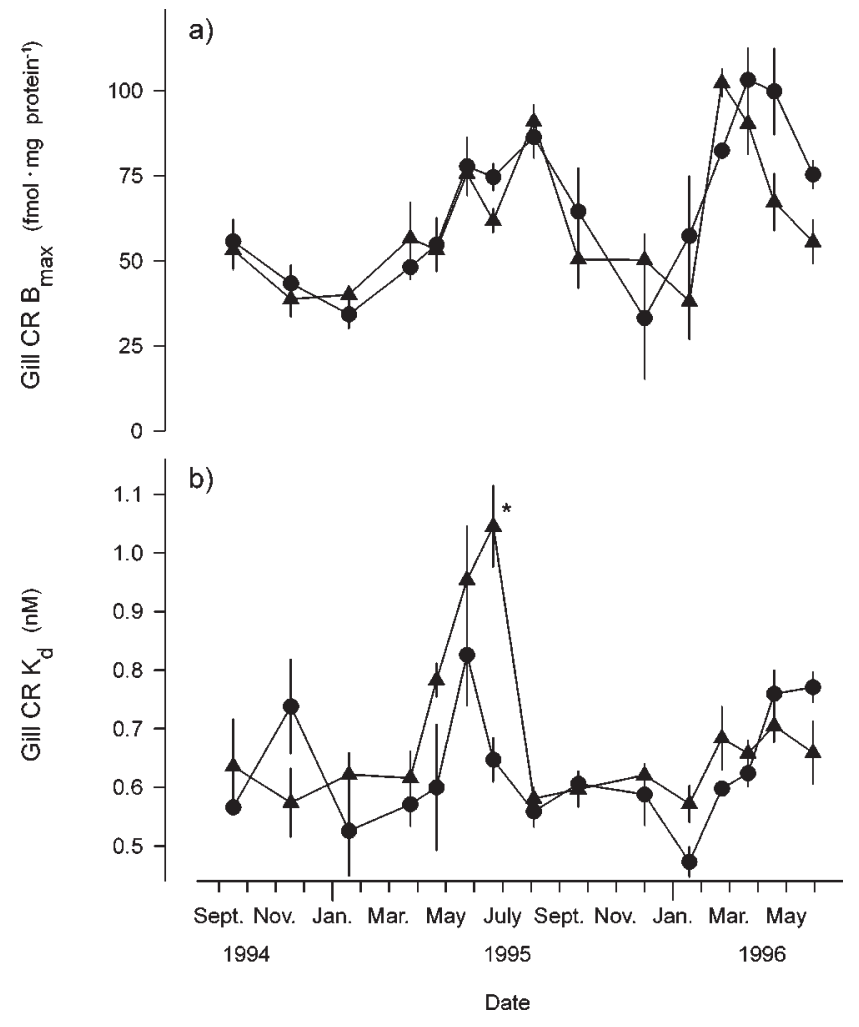

tween the two groups except for June when values for UM fish were significantly greater than those for LM fish. Gill $\mathrm{CR} K_{\mathrm{d}}$ declined significantly in UM fish from June to $\mathrm{Au}-$ gust. From August to January, gill CR $K_{\mathrm{d}}$ showed little seasonal change or differences between groups. From lows in January, gill CR $K_{\mathrm{d}}$ increased in both groups, although the magnitude of the change was less than the previous year. The Hill coefficient did not differ significantly over time or between the two modes and was not significantly different from 1 .

\section{Saltwater challenges}

Saltwater challenge tests were conducted in January and April of the second year on the UM and LM fish (Table 1). UM fish showed high salinity tolerance on both occasions. In contrast, salinity tolerance was low in January for LM fish, with one mortality, but increased in April. Two-way ANOVA indicates that there were no significant differences in salinity tolerance over time $(p=0.3)$ or between modal groups $(p=0.084)$, but there was a significant interaction effect $(p=0.005)$. Tukey's test indicated significant differences in plasma chloride concentration between the two groups in January $(p=0.011)$ but not in April $(p=0.834)$. Comparing the two sample dates, there was no significant difference in plasma chloride concentration for UM fish ( $p=$ $0.569)$, but LM fish showed significantly lower plasma chloride concentrations in April compared with January $(p=0.028)$.
Table 1. Mean weight, plasma chloride concentration, and mortality following $24 \mathrm{~h}$ of exposure to $35 \%$ saltwater.

\begin{tabular}{lllll}
\hline Date and mode & $n$ & $\begin{array}{l}\text { Weight } \\
(\mathrm{g})\end{array}$ & $\begin{array}{l}\text { Plasma chloride } \\
\left(\text { mequiv. } \cdot \mathrm{L}^{-1}\right)\end{array}$ & $\begin{array}{l}\text { Mortality } \\
\text { (no. of fish) }\end{array}$ \\
\hline $\begin{array}{l}\text { January 19, 1996 } \\
\text { LM }\end{array}$ & 12 & $118 \pm 6$ & $184 \pm 5$ & 1 \\
UM & 10 & $453 \pm 41^{*}$ & $164 \pm 3^{*}$ & 0 \\
$\begin{array}{l}\text { April 18, 1996 } \\
\text { LM }\end{array}$ & 12 & $139 \pm 9$ & $167 \pm 4 * *$ & 0 \\
UM & 10 & $641 \pm 57^{*}$ & $172 \pm 3$ & 0 \\
\hline
\end{tabular}

Note: *Significantly different from LM fish for the same sample date; **significantly different from the January value for the same group.

\section{Discussion}

Seasonal changes in morphology and physiology associated with smolting and the development of seawater tolerance were found in UM Atlantic salmon during two consecutive springs and in LM Atlantic salmon in the second year. The capacity for Atlantic salmon to smolt is clearly related to fish achieving a minimum size (Hoar 1988). In the present study, differential growth rates resulted in two easily recognizable groups by the first October (second sampling point) after hatch. UM fish were larger than the minimum size necessary for smolting in the first year, and both groups exceeded the minimum size in the second year (Saunders et al. 1994). Other indices characteristic of smolting were also observed in UM fish in the first spring, such as a decrease in CF (McCormick and Saunders 1987; Hoar 1988). In the first year, the decline in CF in UM fish continued until April and then began to increase in May. LM fish that were not smolting exhibited a decrease in CF until March. Although smolting clearly affected CF, the lowest CFs measured for the first spring and second spring were coincident with the coldest water temperatures of the rearing ponds, indicating that water temperature and potentially appetite (Metcalfe et al. 1988) may also be affecting CF. The larger drop in $\mathrm{CF}$ in LM fish may be related both to their smaller size and to their subordinate position to UM fish, which may have affected their food intake. Another index of smolting, silver colouration and dark fin margins, was characteristic of UM smolts in the first spring. LM fish showed no change in pigmentation until the second spring.

Seasonal changes in gill $\mathrm{Na}^{+}, \mathrm{K}^{+}$-ATPase activity have been reported in both UM and LM juvenile Atlantic salmon during the first year (Duston 1994; Shrimpton and McCormick 1998a), but the magnitude of the increase in gill $\mathrm{Na}^{+}, \mathrm{K}^{+}$-ATPase activity in LM fish $(<4 \mu \mathrm{mol}$ ADP.mg protein $^{-1} \cdot h^{-1}$ ) was not high enough to be characteristic of smolts (McCormick 1993). In the present study, we have shown that spring increases in gill $\mathrm{Na}^{+}, \mathrm{K}^{+}$-ATPase activity also occur in the second year, with both UM and LM fish exhibiting increases in gill $\mathrm{Na}^{+}, \mathrm{K}^{+}$-ATPase activity characteristic of smolts (>6 $\mu \mathrm{mol} \mathrm{ADP} \cdot \mathrm{mg}$ protein ${ }^{-1} \cdot \mathrm{h}^{-1}$ ) (McCormick 1993) and improved salinity tolerance characteristic of smolts. Following smolting in the first spring, gill $\mathrm{Na}^{+}, \mathrm{K}^{+}$-ATPase activity of UM fish decreased dramatically, and salinity tolerance was likely to have also decreased as well 
(McCormick et al. 1999). The salinity tolerance of UM fish was high when measured in January 1996. Increased salinity tolerance with increasing size is a well-known feature of the osmoregulatory physiology of salmonids (McCormick and Saunders 1987), and the high salinity tolerance of UM fish in January was probably due to the large size of these fish ( $>400 \mathrm{~g}$ ). Endocrine factors known to stimulate gill $\mathrm{Na}^{+}, \mathrm{K}^{+}-$ ATPase activity are most notably GH and cortisol. The rise in gill $\mathrm{Na}^{+}, \mathrm{K}^{+}$-ATPase activity in UM fish occurred concomitant with an increase in plasma GH in the first spring. The modest increase in plasma GH during the first spring may also drive the increase in gill $\mathrm{Na}^{+}, \mathrm{K}^{+}$-ATPase activity observed in LM fish. Although little increase in plasma cortisol concentration occurred during the first spring, cortisol may still influence this increase in $\mathrm{Na}^{+}, \mathrm{K}^{+}$-ATPase activity, as $\mathrm{CR}$ concentration increased during this period. During this time, gill CR $B_{\max }$ showed a $50 \%$ increase, which will enhance gill sensitivity to cortisol (Shrimpton and McCormick 1999). High levels of gill $\mathrm{Na}^{+}, \mathrm{K}^{+}$-ATPase activity were sustained in UM fish from April to June 1995, a time when plasma GH and plasma cortisol remained high and gill CR $B_{\max }$ was increasing, indicating that maximal stimulation and responsiveness of the tissue were maintained over this time interval.

In contrast with plasma $\mathrm{GH}$, plasma cortisol levels increased much more in the second year compared with the first. Cortisol levels in UM fish began to increase in January and continued to increase until April. Gill $\mathrm{Na}^{+}, \mathrm{K}^{+}$-ATPase activity increased in February and appeared to lag behind the increase in cortisol in UM fish by 1 month. Highest gill $\mathrm{Na}^{+}, \mathrm{K}^{+}$-ATPase activity occurred in May, despite the decline in circulating levels of cortisol. Unlike UM fish, LM fish had an increase in gill $\mathrm{Na}^{+}, \mathrm{K}^{+}$-ATPase activity that preceded any detectable change in plasma cortisol or GH. Cortisol, however, may still influence this increase in enzyme activity through an increase in gill CR $B_{\max }$, as described above.

In the second spring, the increase in gill $\mathrm{Na}^{+}, \mathrm{K}^{+}$-ATPase activity occurred a full month later than the previous year. Photoperiod and temperature are both known to influence the development of saltwater tolerance in juvenile salmonids (Hoar 1988). Maximal increases have been shown to occur when photoperiod and temperature are both increasing (Muir et al. 1994; see review by McCormick et al. 1997). In the present study, fish were kept under natural photoperiod throughout the experiment, and the stimulus for smolting from photoperiod therefore did not differ between the two years. The differences in timing for the increase in gill $\mathrm{Na}^{+}, \mathrm{K}^{+}$-ATPase activity may be attributable to the lower water temperature during the second spring. Water temperature was colder during the early spring, $2^{\circ} \mathrm{C}$ colder during March and April for the second year. Accumulated degree-days affect the timing of smolting during the spring, as warmer rearing temperature can advance increases in gill $\mathrm{Na}^{+}, \mathrm{K}^{+}$ATPase activity during smolting (McCormick et al. 1997). Differences in endocrine changes between the first and second spring may also be linked to temperature. Compared with the first year, plasma GH levels increased less during the second year, with only a 50\% increase in circulating levels of GH in UM and LM fish. Low water temperature during the spring and in May $\left(5.4^{\circ} \mathrm{C}\right.$ on May 15) may have inhibited the increase in plasma GH. Björnsson et al. (1989) showed that rearing fish at a constant temperature of $6^{\circ} \mathrm{C}$ inhibited an increase in plasma GH in Atlantic salmon, and McCormick et al. (2000) found that low temperature can significantly delay photoperiod-induced increases in GH levels during Atlantic salmon smoltification. The differences in GH between the two years may be due to the colder temperature in the second year. While strong evidence exists for a direct role of GH on smolting, large increases in circulating levels may not be necessary for smolting, as relatively small increases in GH levels have been correlated with increased seawater tolerance and growth rate during Atlantic salmon smoltification (Björnsson et al. 1995).

CR concentration has been observed to change seasonally with smolting in coho salmon (Shrimpton 1996), Atlantic salmon (Shrimpton and McCormick 1998a), and hybrid steelhead-rainbow trout (Oncorhynchus mykiss) but not in steelhead trout (McLeese et al. 1994). Throughout the first year, there was little difference in gill CR $B_{\max }$ between UM and LM fish, consistent with the findings of Shrimpton and McCormick (1998a). This is surprising, however, as there were large differences between the groups in GH levels, a hormone shown to increase gill CR $B_{\max }$ (Shrimpton et al. 1995; Shrimpton and McCormick 1998b). Gill CR $B_{\max }$, however, differed between LM and UM fish in the second year. The reason for the observed differences in gill $\mathrm{CR} B_{\max }$ may be due to cortisol, which has been shown to downregulate CR $B_{\max }$ in coho salmon gill (Maule and Schreck 1991; Shrimpton and Randall 1994) and rainbow trout liver (Pottinger et al. 1994). As cortisol levels were low and showed little change in the first spring, it may have contributed little to the changes in gill CR $B_{\max }$. During the second spring, gill CR $B_{\max }$ declined significantly in UM fish from February to May; in LM fish, the decline occurred from April to May. Cortisol was higher earlier in UM fish and this corresponded to an earlier decline in gill CR $B_{\max }$ than in LM fish.

Gill CR affinity decreases have been observed seasonally in coho salmon (Shrimpton 1996) and Atlantic salmon (Shrimpton and McCormick 1998a) but not in steelhead trout (McLeese et al. 1994). In this study, we found an increase in gill CR $K_{\mathrm{d}}$ associated with smolting. Cortisol treatment decreases CR affinity in coho salmon gill (Maule and Schreck 1991; Shrimpton and Randall 1994) and rainbow trout liver (Pottinger et al. 1994). In both years, cortisol increased synchronously with increased gill CR $K_{\mathrm{d}}$; however, the magnitude of the change in cortisol did not correlate with the magnitude of change seen in gill CR $K_{\mathrm{d}}$. Changes in gill CR $K_{\mathrm{d}}$ were larger in the first year than in the second, whereas the plasma cortisol levels showed the opposite trend. Also, despite the large increase in plasma cortisol in April in UM and LM fish, values of gill CR $K_{\mathrm{d}}$ did not differ between April and May. The absence of any change in circulating cortisol levels in LM fish further suggests that cortisol may not be the primary inducer of seasonal changes in gill CR $K_{\mathrm{d}}$ in Atlantic salmon in the present study. Other hormones may contribute to seasonal changes in gill CR $K_{\mathrm{d}}$. Exogenous administration of $\mathrm{GH}$ to Atlantic salmon parr significantly increased gill CR $K_{\mathrm{d}}$ (Shrimpton and McCormick 1998b). Thus, the high plasma GH levels in the UM fish during the first spring may have contributed to the increased gill CR $K_{\mathrm{d}}$ in the UM group. 
The significant decline in gill $\mathrm{Na}^{+}, \mathrm{K}^{+}$-ATPase activity from June to August in both UM and LM fish occurred at the same time as the decrease in plasma GH and, to a lesser extent, cortisol. Loss of smolt characteristics occurs in Atlantic salmon that remain in freshwater beyond the normal date of entry into seawater. The stock used in the present study (McCormick et al. 1999) and other stocks (Lundqvist et al. 1989) of Atlantic salmon smolts held in freshwater after the period of seawater migration show a loss of hypoosmoregulatory ability and gill $\mathrm{Na}^{+}, \mathrm{K}^{+}$-ATPase activity. This loss of smolt characteristics is temperature dependent (Duston et al. 1991; McCormick et al. 1997). The relatively low summer temperature may have thus contributed to the persistent elevation in gill $\mathrm{Na}^{+}, \mathrm{K}^{+}$-ATPase activity seen in UM fish. McCormick et al. (1997) found a relationship between the length of time that fish show increased gill $\mathrm{Na}^{+}, \mathrm{K}^{+}$-ATPase activity and water temperature; the duration of smolting was inversely related to water temperature. The decline in gill $\mathrm{Na}^{+}, \mathrm{K}^{+}$-ATPase activity is inevitable, even though gill sensitivity to cortisol remains high as assessed by gill CR $B_{\max }$. In contrast with the findings of Shrimpton and McCormick (1998a), gill CR $B_{\max }$ remained high following the decline in gill $\mathrm{Na}^{+}, \mathrm{K}^{+}$-ATPase activity.

The UM fish in this study exhibited good saltwater tolerance in January, a time of year when Atlantic salmon do not typically migrate into salt water. This indicates that UM fish in their second spring can tolerate short-term exposure to seawater independent of the seasonal increase in gill $\mathrm{Na}^{+}, \mathrm{K}^{+}$-ATPase activity. This is probably size related. In contrast, LM fish exhibited a weaker ability to hypoosmoregulate than UM fish in January, resulting in a greater perturbation in plasma chloride. An increase in saltwater tolerance of LM fish was observed in April in association with elevated gill $\mathrm{Na}^{+}, \mathrm{K}^{+}$-ATPase activity. At sizes typical for smolts, salinity tolerance is strongly connected to increased gill $\mathrm{Na}^{+}, \mathrm{K}^{+}$-ATPase activity, whereas at larger sizes, salinity tolerance may be independent of the seasonal changes in gill $\mathrm{Na}^{+}, \mathrm{K}^{+}$-ATPase activity.

In conclusion, our findings indicate that Atlantic salmon are capable of undergoing the physiological changes associated with smolting in two successive years. UM fish that are not allowed to enter seawater as smolts during the first year have the potential to repeat the physiological process of parr-smolt transformation the following year. Whether this occurs in the wild is not known, but it is plausible that natural phenomena such as severe draughts or temporary river blockages may at times obstruct the natural downstream migration and force fish to spend another year in the freshwater environment.

\section{Acknowledgments}

We thank the staff of the White River National Fish Hatchery, U.S. Fish and Wildlife Service, for providing and maintaining the fish used throughout the study. We also thank Judy Carey, Jill Leonard, Michael O'Dea, and Joseph Zydlewski for their assistance sampling the fish. We express our gratitude to Judy Carey for cortisol analyses and Gunilla Eriksson for GH analyses. This study was partly financed by the Swedish Council for Agricultural and Forestry Research.

\section{References}

Björnsson, B.Th. 1997. The biology of salmon growth hormone: from daylight to dominance. Fish Physiol. Biochem. 17: 9-24.

Björnsson, B.Th., Thorarensen, H., Hirano, T., Ogasawara, T., and Kristinsson, J.B. 1989. Photoperiod and temperature affect plasma growth hormone levels, growth, condition factor and hypoosmoregulatory ability of juvenile Atlantic salmon (Salmo salar) during parr-smolt transformation. Aquaculture, 82: 77-91.

Björnsson, B.Th., Taranger, G.L., Hansen, T., Stefansson, S.O., and Haux, C. 1994. The interrelation between photoperiod, growth hormone, and sexual maturation of adult Atlantic salmon (Salmo salar). Gen. Comp. Endocrinol. 93: 70-81.

Björnsson, B.Th., Stefansson, S.O., and Hansen, T. 1995. Photoperiod regulation of plasma growth hormone levels during parrsmolt transformation of Atlantic salmon: implications for hypoosmoregulatory ability and growth. Gen. Comp. Endocrinol. 100: $73-82$.

Boeuf, G., Prunet, P., and Le Bail, P.Y. 1990. Un traitment à l'hormone de croissance peut-it stimuler la smoltification du saumon atlantique? C.R. Hebd. Séances Acad. Sci. Paris, 310(III): 75-80.

Carey, J.B., and McCormick, S.D. 1998. Atlantic salmon smolts are more responsive to handling and confinement stress than parr. Aquaculture, 168: 237-253.

Duston, J. 1994. Effect of salinity on survival and growth of Atlantic salmon (Salmo salar) parr and smolts. Aquaculture, 121: $115-124$.

Duston, J., Saunders, R.L., and Knox, D.E. 1991. Effects of increase in freshwater temperature on loss of smolt characteristics in Atlantic salmon (Salmo salar). Can. J. Fish. Aquat. Sci. 48: 164-169.

Heggenes, J., and Metcalfe, N.B. 1991. Bimodal size distributions in wild juvenile Atlantic salmon populations and their relationship with age at smolt migration. J. Fish Biol. 39: 905-907.

Hoar, W.S. 1988. The physiology of smolting salmonids. In Fish physiology. Vol. XIB. Edited by W.S. Hoar and D.J. Randall. Academic Press, New York. pp. 275-344.

Lundqvist, H., Borg, B., and Berglund, I. 1989. Androgens impair seawater adaptability in smolting Baltic salmon (Salmo salar). Can. J. Zool. 67: 1733-1736.

Madsen, S.S. 1990. Enhanced hypoosmoregulatroy response to growth hormone after cortisol treatment in immature rainbow trout, Salmo gairdneri. Fish Physiol. Biochem. 8: 271-279.

Maule, A.G., and Schreck, C.B. 1991. Stress and cortisol treatment changed affinity and number of glucocorticoid receptors in leukocytes and gill of coho salmon. Gen. Comp. Endocrinol. 84: 83-93.

McCormick, S.D. 1993. Methods for nonlethal gill biopsy and measurements of $\mathrm{Na}^{+}, \mathrm{K}^{+}$-ATPase activity. Can. J. Fish. Aquat. Sci. 50: 656-658.

McCormick, S.D. 1995. Hormonal control of gill Na+,K+-ATPase and chloride cell function. In Fish physiology, ionoregulation: cellular and molecular approaches. Edited by C.M. Wood and T.J. Shuttleworth. Academic Press, New York. pp. 285-313.

McCormick, S.D., and Saunders, R.L. 1987. Preparatory physiological adaptations for marine life of salmonids: osmoregulation, growth, and metabolism. Am. Fish. Soc. Symp. 1: 211-229.

McCormick, S.D., Björnsson, B.Th., Sheridan, M., Eilertson, C., Carey, J.B., and O'Dea, M. 1995. Increased daylength stimulates plasma growth hormone and gill $\mathrm{Na}^{+}, \mathrm{K}^{+}$-ATPase in Atlantic salmon (Salmo salar). J. Comp. Physiol. B, Biochem. Syst. Environ. Physiol. 165: 245-254. 
McCormick, S.D., Shrimpton, J.M., and Zydlewski, J.D. 1997. Temperature effects on osmoregulatory physiology of juvenile anadromous fish. In Society for Experimental Biology Seminar Series 61: Global warming: implications for freshwater and marine fish. Edited by C.M. Wood and D.G. McDonald. Cambridge University Press, Cambridge. pp. 279-301.

McCormick, S.D., Cunjak, R.A., Dempson, B., O’Dea, M.F., and Carey, J.B. 1999. Temperature-related loss of smolt characteristics in Atlantic salmon in the wild. Can. J. Fish. Aquat. Sci. 56: 1649-1667.

McCormick, S.D., Moriyama, S., and Björnsson, B.Th. 2000. Low temperature limits the photoperiod response: endocrinology of smolting in Atlantic salmon. Am. J. Physiol. 278: R1352-R1361.

McLeese, J.M., Johnsson, J., Huntley, F.M., Clarke, W.C., and Weisbart, M. 1994. Seasonal changes in osmoregulation, cortisol, and cortisol receptor activity in the gills of parr/smolt of steelhead trout and steelhead-rainbow trout hybrids, Oncorhynchus mykiss. Gen. Comp. Endocrinol. 93: 103-113.

Metcalfe, N.B., Huntingford, F.A., and Thorpe, J.E. 1988. Feeding intensity, growth rates, and the establishment of life-history patterns in juvenile Atlantic salmon, Salmo salar. J. Anim. Ecol. 57: 463-474.

Muir, W.D., Zaugg, W.S., Giorgi, A.E., and McCutcheon, S. 1994. Accelerating smolt development and downstream movement in yearling chinook salmon with advanced photoperiod and increased temperature. Aquaculture, 123: 387-399.

Pottinger, T.G., Knudsen, F.R., and Wilson, J. 1994. Stress-induced changes in the affinity and abundance of cytosolic cortisolbinding sites in the liver of rainbow trout, Oncorhynchus mykiss (Walbaum), are not accompanied by changes in measurable nuclear binding. Fish Physiol. Biochem. 12: 499-511.

Sandor, T., DiBattista, J.A., and Mehdi, A.Z. 1984. Glucocorticoid receptors in the gill tissue of fish. Gen. Comp. Endocrinol. 53: 353-364.

Saunders, R.L., Duston, J., and Benfey, T.J. 1994. Environmental and biological factors affecting growth dynamics in relation to smolting of Atlantic salmon, Salmo salar L. Aquacult. Fish. Manage. 25: 9-20.
Scatchard, G. 1949. The attraction of protein for small molecules and ions. Ann. N.Y. Acad. Sci. 51: 661-672.

Shrimpton, J.M. 1996. Relationship between size, gill corticosteroid receptors, $\mathrm{Na}^{+}, \mathrm{K}^{+}$-ATPase activity and smolting in juvenile coho salmon (Oncorhynchus kisutch) in autumn and spring. Aquaculture, 147: 127-140.

Shrimpton, J.M., and McCormick, S.D. 1998a. Seasonal differences in plasma cortisol and gill corticosteroid receptors in upper and lower mode juvenile Atlantic salmon. Aquaculture, 168: 205-219.

Shrimpton, J.M., and McCormick, S.D. 1998b. Regulation of gill cytosolic corticosteroid receptors in juvenile Atlantic salmon: interaction effects of growth hormone with prolactin and triiodothyronine. Gen. Comp. Endocrinol. 112: 262-274.

Shrimpton, J.M., and McCormick, S.D. 1999. Responsiveness of gill $\mathrm{Na}^{+}, \mathrm{K}^{+}$-ATPase to cortisol is related to gill corticosteroid receptor concentration in juvenile rainbow trout. J. Exp. Biol. 202: 987-995.

Shrimpton, J.M., and Randall, D.J. 1994. Downregulation of corticosteroid receptors in the gills of coho salmon due to stress and cortisol treatment. Am. J. Physiol. 267: R432-R438.

Shrimpton, J.M., Devlin, R.H., McLean, E., Byatt, J.C., Donaldson, E.M., and Randall, D.J. 1995. Increases in gill cytosolic corticosteroid receptor abundance and saltwater tolerance in juvenile coho salmon (Oncorhynchus kisutch) treated with growth hormone and placental lactogen. Gen. Comp. Endocrinol. 98: 1-15.

Sumpter, J.P., Dye, H.M., and Benfey, T.J. 1986. The effect of stress on plasma ACTH, $\alpha-\mathrm{MSH}$, and cortisol in salmonid fishes. Gen. Comp. Endocrinol. 62: 377-385.

Thorpe, J.E., Morgan, R.I.G., Ottaway, E.M., and Miles, M.S. 1980. Time of divergence of growth groups between potential $1^{+}$ and $2^{+}$smolts among sibling Atlantic salmon. J. Fish Biol. 17: $13-21$.

Welshons, W.V., and Jordon, V.C. 1987. Heterogeneity of nuclear steroid hormone receptors with an emphasis on unfilled receptor sites. In Steroid hormones: their intracellular localization. Edited by C.R. Clark. Ellis Horwood, Chichester, U.K. pp. 128-154. 